\title{
Effect of Statins on Aneurysmal Subarachnoid Hemorrhage: A Meta-Analysis of Randomized Controlled Trials
}

\section{Anevrizmal Subaraknoid Kanamaya Statinlerin Etkisi: Randomize Kontrollï Calışmalarn Bir Meta-Analizi}

\author{
Bin-Fei ZHANG ${ }^{*}$, Jin-Ning $\mathrm{SONG}^{1^{*}}$, Jiao $\mathrm{WANG}^{2}$, Xu-Dong $\mathrm{MA}^{1}$, Shi-Tao ZHANG ${ }^{1}$, Jun-Jie ZHAO${ }^{1}$, \\ Kun SHU ${ }^{1}$, Peng SUN ${ }^{1}$, Yong-Lin $\mathrm{ZHAO}^{1}$ \\ ${ }_{1}^{1}$ Medical School of Xi'an Jiaotong University, The First Affiliated Hospital, Department of Neurosurgery, Xi'an, Shaanxi Province, China \\ ${ }^{2}$ Medical School of Xi'an Jiaotong University, The First Affiliated Hospital, Department of Rehabilitation Medicine, Xi'an, Shaanxi Province, \\ China \\ *These authors contributed equally to this work and should be considered co-first authors.
}

Corresponding Author: Jin-Ning SONG / E-mail: jinningsong@126.com

\begin{abstract}
AIM: The role of statins for treating aneurysmal subarachnoid hemorrhage (aSAH) remains uncertain. In this study, the relevance of different end points was evaluated in order to clarify the action and efficacy of statins.

MATERIAL and METHODS: A systematic literature retrieval was carried out to obtain randomized controlled trials (RCTs) from before March 2013 on the use of statins for aSAH. Data extraction and quality evaluation of the studies were performed by 2 investigators. A meta-analysis was performed using Review Manager (RevMan) software version 5.2.3.

RESULTS: Seven randomized controlled trials comprising 347 patients that met the inclusion criteria were included in this meta-analysis. Results showed that, in $\mathrm{aSAH}$, statins did not reduce vasospasm on transcranial Doppler ( $\mathrm{RR}=0.80 ; 95 \% \mathrm{Cl}, 0.53-1.21 ; \mathrm{p}=0.29)$ or improve outcomes ( $R R=0.92 ; 95 \% \mathrm{Cl}, 0.71-1.20 ; \mathrm{p}=0.54$ ). However, statins were able to decrease delayed ischemic neurological deficits (RR=0.56; $95 \%$ $\mathrm{Cl}, 0.41-0.75 ; \mathrm{p}=0.0001)$ and mortality $(\mathrm{RR}=0.54 ; 95 \% \mathrm{Cl}, 0.32-0.91 ; \mathrm{p}=0.02)$ compared with placebo.
\end{abstract}

CONCLUSION: Acute statin treatment might not be a good choice for cerebral vasospasm after aSAH. Further large-scale, well-designed RCTs on this topic are still needed.

KEYWORDS: Statins, Aneurysmal subarachnoid hemorrhage, Meta-analysis, Transcranial doppler

öz

AMAÇ: Anevrizmal subaraknoid kanamayı (aSAK) tedavi etmekte statinlerin rolü halen kesin değildir. Bu çalışmada statinlerin etkisi ve etkinliğini açıklığa kavuşturmak için farklı son noktaların önemi değerlendirilmiştir.

YÖNTEM ve GEREÇLER: Mart 2013 öncesinde aSAK için statinlerin kullanımı konusunda randomize kontrollü çalışmaları bulmak için sistematik bir literatür taraması yapılmıştır. Çalışmalardan verilerin alınması ve kalitelerinin değerlendirilmesi 2 araştırmacı tarafından gerçekleştirilmiştir. Review Manager (RevMan) yazılımı versiyon 5.2.3 kullanılarak bir meta-analiz yapılmıştır.

BULGULAR: Bu meta analize çalışmaya alma kriterlerini karşılayan 347 hastalık yedi randomize kontrollü çalışma dahil edilmiştir. Sonuçlar aSAK durumunda statinlerin transkraniyal Doppler'de vazospazmı azaltmadığını $(R R=0,80 ; \% 95 \mathrm{GA}, 0,53-1,21 ; p=0,29)$ veya sonuçları daha iyi hale getirmediğini $(\mathrm{RR}=0,92 ; \% 95 \mathrm{Cl}, 0,71-1,20 ; \mathrm{p}=0,54)$ göstermiş̧tir. Ancak statinler plaseboyla karşılaştırıldığında gecikmiş iskemik nörolojik defisitleri ( $R R=0,56 ; \% 95 \mathrm{GA}, 0,41-0,75 ; p=0,0001)$ ve mortaliteyi ( $R R=0,54 ; \% 95 \mathrm{GA}, 0,32-0,91 ; p=0,02)$ azaltmıştır.

SONUÇ: Akut statin tedavisi aSAK sonrasında serebral vazospazm için iyi bir tercih olmayabilir. Bu konuda daha büyük ölçekli ve iyi tasarlanmış randomize kontrollü çalışmalar gereklidir.

ANAHTAR SÖZCÜKLER: Statinler, Anevrizmal subaraknoid kanama, Meta-analiz, Transkraniyal doppler 


\section{INTRODUCTION}

Subarachnoid hemorrhage (SAH) is one of the most common cerebrovascular events. Every year, approximately 30,000 people in the United States experience an SAH (28). Early brain injury (27), cerebral vasospasm (CVS) (26), and delayed ischemic neurological deficit (DIND) (12) after aneurysmal SAH (aSAH) strongly determine the patient's prognosis. Many treatment options for preventing these complications are available in clinical practice.

Statins have been administered for aSAH. Atorvastatin can reduce the incidence and severity of CVS and suppress a biomarker of cerebral ischemia after aSAH (20). Simvastatin has a beneficial therapeutic effect on reducing cognitive dysfunction after aSAH (16). Clinical trials have demonstrated that simvastatin reduces CVS and mortality and improves functional outcomes, although these findings were not statistically significant (4). Patients who are treated with statins prior to aSAH tend to have a lower incidence of subsequent CVS (17). However, other studies have shown that simvastatin does not exert a beneficial effect on patients with aSAH $(8,9)$. Kramer et al. (11) pointed out that if there is a benefit to statin use, it may be smaller than suggested by previous studies.

Thus, the role of statins for treating patients with aSAH remains unclear. The designers of various studies considered whether or not statins reduce the likelihood of CVS and DIND. Therefore, in this analysis, we evaluated the efficacy of statins by comparing different reported outcomes in order to discuss the role of statins for treating aSAH.

\section{MATERIAL and METHODS}

\section{Inclusion Criteria}

First, RCTs only were selected, but blinding and allocation concealment were not initially considered. Second, participants were included according to age ( $>18$ years), a diagnosis of aSAH after emergency hospital admission, and initial aSAH grade according to the World Federation of Neurological Surgeons scale; a computed tomography scan of the head was assessed within 24 hours. All patients underwent endovascular coiling or surgical clipping for aneurysm during the first 72 hours of ictus. After undergoing coiling or clipping for aneurysm, patients were randomly allocated to the statin group or the placebo group. The statin group had received simvastatin or pravastatin, and the placebo group had received placebo or nonstatin treatment for 14 or more days. The primary end points were CVS on transcranial Doppler (TCD), DIND, poor outcome, and mortality. Secondary end points were time to CVS and DIND from ictus, duration of CVS and DIND, and adverse events at follow-up.

\section{Literature Search}

Our literature search followed the methodological guidelines in the Cochrane Handbook for Systematic Reviews of Interventions version 5.1.0. Three search engines were used: Medline, EMBASE, and the Cochrane Library, and results were retrieved with following words: Subarachnoid Hemorrhage, statin, simvastatin, pravastatin, and HydroxymethylglutarylCoA Reductase Inhibitors. The search process did not set a limit on results. In addition, the references listed at the end of the studies were manually checked to filter in potentially eligible studies. The last date reached by the search was March 2013.

\section{Data Extraction and Quality Evaluation}

Two investigators (Xu-Dong Ma and Shi-Tao Zhang) independently read titles and abstracts, excluding trials that did not match the inclusion criteria. Patients' baseline characteristics and details of the study designs were extracted from the included studies. Inconsistent data were extracted by a third investigator (Jun-Jie Zhao).

We evaluated the methodological quality of the studies based on criteria described in the Cochrane Handbook 5.1.0, including random-sequence generation, allocation concealment, blinding, and incomplete outcome data. In order to describe those aspects of every study, investigators chose the terms "low risk of bias," "high risk of bias," or "unclear" (lacking information or of uncertain bias) to define each study. To clarify ambiguous information about study design or data, investigators contacted authors by e-mail.

\section{Statistical Methods}

For calculating the effective size of dichotomous variables, relative risk $(R R)$ was used. Effective size described with 95\% confidence intervals ( $\mathrm{Cls}$ ). Before analyzing trial data, the heterogeneity of the trials was tested using $l^{2}$ statistics, a quantitative method for measuring inconsistency across studies. Outcomes with an $P^{2}$ statistic of $25 \%-50 \%$ were considered to have low heterogeneity, an $P^{2}$ statistic of $50 \%-75 \%$ was linked to moderate heterogeneity, and an $P^{2}$ statistic of $>75 \%$ demonstrated high heterogeneity (5). An $I^{2}$ value $>50 \%$ indicated significant heterogeneity. A fixedeffects model was appropriate for analyzing studies with low heterogeneity $\left(I^{2}<50 \%\right)$, and a random-effects model was used to analyze the outcome of studies with significant heterogeneity $\left(I^{2}>50 \%\right)(1)$. When statistical heterogeneity existed without clinical heterogeneity among various studies, the random-effects model was also used.

Investigators further conducted sensitivity analyses to explore possible explanations for heterogeneity in the overall pooled estimate. For conclusions, a probability value of $P<0.05$ was considered statistically significant for differences. All statistical analyses were performed using Review Manager (RevMan) software version 5.2.3 software (The Nordic Cochrane Centre, The Cochrane Collaboration, Copenhagen, Denmark).

\section{RESULTS}

\section{Process for Included Trials}

A total of 95 studies were identified from 3 databases. After reading the titles and abstracts, 78 studies were excluded because they were duplications, reviews, case reports, or animal experiments; the remaining 17 trials focused on 
statins for treating aSAH. Of these 17 studies included in the meta-analysis, 5 were concerned with the biological effects of statins, 5 were controlled trials that enrolled 930 patients to study clinical efficacy, and 7 were RCTs that enrolled 347 patients and that met the inclusion criteria $(2,4,7,13,14,23$, 25).

\section{Characteristics of Included Trials and Quality Evaluation}

The main characteristics of the trials included in the metaanalysis are shown in Table 1. Seven studies were published between 2005 and 2013, most of which had small sample size. In 7 of the studies included in this analysis, $2(7,23)$ administered pravastatin or placebo to 178 participates, and $5(2,4,13,14,25)$ administered simvastatin or placebo to 169 patients.

The methodological quality of trials is shown graphically in Figures 1 and 2. Figure 1 shows the risk of bias for included studies, and Figure 2 represents the overall bias of every study aspect. Five trials $(2,4,13,23,25)$ were randomized, double-blind, placebo-controlled trials; 2 trials $(7,14)$ were randomized only in the choice of statin or nonstatin treatment, without a blinding method. Four trials $(2,13,23,25)$ included an intention-to-treat analysis.

Table I: Characteristics of Trials Included in the Meta-Analysis

\begin{tabular}{|c|c|c|c|c|c|}
\hline $\begin{array}{l}\text { First Author } \\
\text { (Year of } \\
\text { Publication) }\end{array}$ & $\begin{array}{l}\text { No. of } \\
\text { Patients } \\
\text { (Statin/ } \\
\text { Placebo } \\
\text { Group) }\end{array}$ & Patient Characteristics & Statin Group & $\begin{array}{l}\text { Placebo } \\
\text { Group } \\
\text { Regimen }\end{array}$ & Definitions of CVS \\
\hline $\begin{array}{l}\text { Tseng } \\
(2005)(23)\end{array}$ & $80(40 / 40)$ & $\begin{array}{l}\text { Patients with aSAH (18-84 } \\
\text { years old); clipping/coiling } \\
\text { was performed in } 27 / 7 \text { in } \\
\text { the statin group and } 25 / 6 \\
\text { in the placebo group }\end{array}$ & $\begin{array}{l}\text { Capsules containing } \\
\text { pravastatin } 40 \mathrm{mg} / \mathrm{d} \text { were } \\
\text { commenced within } 72 \mathrm{~h} \\
\text { of ictus and continued for } \\
14 \mathrm{~d} \text { or until discharge }\end{array}$ & $\begin{array}{l}\text { Capsules } \\
\text { containing } \\
\text { lactose }\end{array}$ & $\begin{array}{l}\text { Velocities in MCA on } \\
\mathrm{TCD}>120 \mathrm{~cm} / \mathrm{s} \text { with } \\
\text { Lindegaard ratio }>3\end{array}$ \\
\hline $\begin{array}{l}\text { Jaschinski } \\
\text { (2008) (7) }\end{array}$ & $98(40 / 58)$ & $\begin{array}{l}\text { Patients ( } 20-80 \text { years old) } \\
\text { with aSAH }\end{array}$ & $\begin{array}{l}\text { Pravastatin }(40 \mathrm{mg} / \mathrm{d}) \\
\text { within } 24 \mathrm{~h} \text { after the ictus }\end{array}$ & $\begin{array}{l}\text { Nonstatin } \\
\text { treatment }\end{array}$ & No reported \\
\hline $\begin{array}{l}\text { Lynch } \\
(2005)(13)\end{array}$ & $39(19 / 20)$ & $\begin{array}{l}\text { Patients presenting within } \\
48 \mathrm{~h} \text { of aSAH; clipping/ } \\
\text { coiling was performed in } \\
9 / 10 \text { in the statin group } \\
\text { and } 8 / 12 \text { in the placebo } \\
\text { group }\end{array}$ & $\begin{array}{l}\text { Simvastatin } 80 \mathrm{mg} / \mathrm{d} \text { for } \\
14 \mathrm{~d}\end{array}$ & $\begin{array}{l}\text { Placebo for } \\
14 d\end{array}$ & $\begin{array}{l}\text { TCD velocities }>160 \\
\mathrm{~cm} / \mathrm{s}\end{array}$ \\
\hline $\begin{array}{l}\text { Chou } \\
(2008)(2)\end{array}$ & $39(19 / 20)$ & $\begin{array}{l}\text { Adults (aged }>18 \text { years) } \\
\text { with Fisher grade } 3 \mathrm{SAH} \\
\text { were included; clipping } \\
\text { was performed in } 17 \text { and } \\
16 \text { patients in the statin } \\
\text { group and placebo group, } \\
\text { respectively }\end{array}$ & $\begin{array}{l}\text { Simvastatin } 80 \mathrm{mg} / \mathrm{d} \\
\text { until discharge from } \\
\text { neurointensive care unit, } \\
\text { or } \leq 21 \mathrm{~d}\end{array}$ & $\begin{array}{l}\text { Placebo } \\
\text { treatment }\end{array}$ & $\begin{array}{l}\text { CVS on TCD was } \\
\text { defined as any peak } \\
\text { systolic MCA velocity } \\
>200 \mathrm{~cm} / \mathrm{s} \text { and } \\
\text { Lindegaard ratio >3 }\end{array}$ \\
\hline $\begin{array}{l}\text { Vergouwen } \\
\text { (2009) (25) }\end{array}$ & $32(16 / 16)$ & $\begin{array}{l}\text { Patients with symptoms } \\
\text { and signs of SAH; clipping } \\
\text { was performed in } 7 \\
\text { patients and coiling in } 24 \\
\text { patients }\end{array}$ & $\begin{array}{l}\text { Capsules containing } \\
\text { simvastatin } 80 \mathrm{mg} / \mathrm{d} \text { until } \\
\text { d } 14 \text { after SAH }\end{array}$ & $\begin{array}{l}\text { Capsules } \\
\text { containing } \\
\text { placebo }\end{array}$ & $\begin{array}{l}\text { TCD velocities } \\
>120 \mathrm{~cm} / \mathrm{s}\end{array}$ \\
\hline $\begin{array}{l}\text { Macedo } \\
(2009)(14)\end{array}$ & $21(11 / 10)$ & Patients with aSAH & Simvastatin $80 \mathrm{mg} / \mathrm{d}$ & $\begin{array}{l}\text { Nonstatin } \\
\text { treatment }\end{array}$ & Not reported \\
\hline $\begin{array}{l}\text { Garg } \\
(2013)(4)\end{array}$ & $38(19 / 19)$ & $\begin{array}{l}\text { All patients ( }>18 \text { years } \\
\text { old) underwent surgical } \\
\text { clipping with evidence of } \\
\text { aSAH }\end{array}$ & $\begin{array}{l}\text { Simvastatin } 80 \mathrm{mg} / \mathrm{d} \text { for } \\
14 \mathrm{~d}\end{array}$ & $\begin{array}{l}\text { Placebo for } \\
14 d\end{array}$ & $\begin{array}{l}\text { TCD velocities } \\
>160 \mathrm{~cm} / \mathrm{s}\end{array}$ \\
\hline
\end{tabular}

CVS: cerebral vasospasm, SAH: subarachnoid hemorrhage, MCA: middle cerebral artery, TCD: transcranial Doppler, aSAH: aneurysmal SAH. 


\section{META-ANALYSIS RESULTS}

\section{Primary end Points}

Six studies $(2,4,13,14,23,25)$ reported CVS on TCD at followup. The aggregated results of these studies suggested that statins did not reduce CVS $(R R=0.80 ; 95 \% \mathrm{Cl}, 0.53-1.21 ; P=0.29)$ (Figure 3), and the statistical test result for heterogeneity was moderate $\left(I^{2}=52 \%, p=0.06\right)$. Six studies $(2,4,7,13,23,25)$ reported DIND; their results indicated that statins reduced DIND ( $R R=0.56 ; 95 \% \mathrm{Cl}, 0.41-0.75 ; p=0.0001)$ (Figure 4), and the statistical test result for heterogeneity was low $\left(I^{2}=16 \%\right.$, $p=0.31)$. Clinical outcome was reported in 6 studies $(2,4,7$, $14,23,25)$; in these studies, statins did not improve outcomes $(R R=0.92 ; 95 \% \mathrm{Cl}, 0.71-1.20 ; p=0.54)$ (Figure 5$)$, and the test result for heterogeneity was low $\left(I^{2}=0 \%, p=0.81\right)$, but results demonstrated that statins were able to reduce mortality in 6 studies $(2,4,7,14,23,25)(R R=0.54 ; 95 \% \mathrm{Cl}, 0.32-0.91 ; p=0.02)$ (Figure 6), and for this end point, the test for heterogeneity was low $\left(I^{2}=13 \%, p=0.33\right)$.

\section{Secondary end points}

Owing to the lack of data, most study results could not be quantitatively analyzed. Thus, descriptive results were as follows: time to CVS from ictus in the statin group was similar to that of the placebo group. For example, Tseng et al. (23) reported the same average time of CVS onset from ictus as 5.2 days in both groups; Chou et al. showed that time to MCA velocity $>200 \mathrm{~cm} / \mathrm{s}$ was $5.9 \pm 2.0$ days in the simvastatin group and $4.8 \pm 1.4$ days in the placebo group (2). Tseng et al. reported time to DIND from ictus as 5.6 days, and Chou et al. reported $6.2 \pm 2.6$ days in the simvastatin group and $5.4 \pm 1.9$ days in the placebo group $(2,23)$. Vergouwen et al. reported that signs of DIND started at a median of 6 days, similar in both treatment groups (25). Overall, statins did not seem to delay time to CVS and DIND from ictus.

The duration of CVS was reported in 2 trials. Tseng et al. described statins as absolutely shortening the duration of CVS by 1.2 days (23). Chou et al. reported a median duration of CVS of 4 days in the simvastatin group and 1 day in the placebo group (2). Thus, statins might be able to shorten the duration of CVS in these patients.

The adverse events reported in 3 studies $(2,4,13)$ showed no significant changes in the level of creatine kinase/aspartate
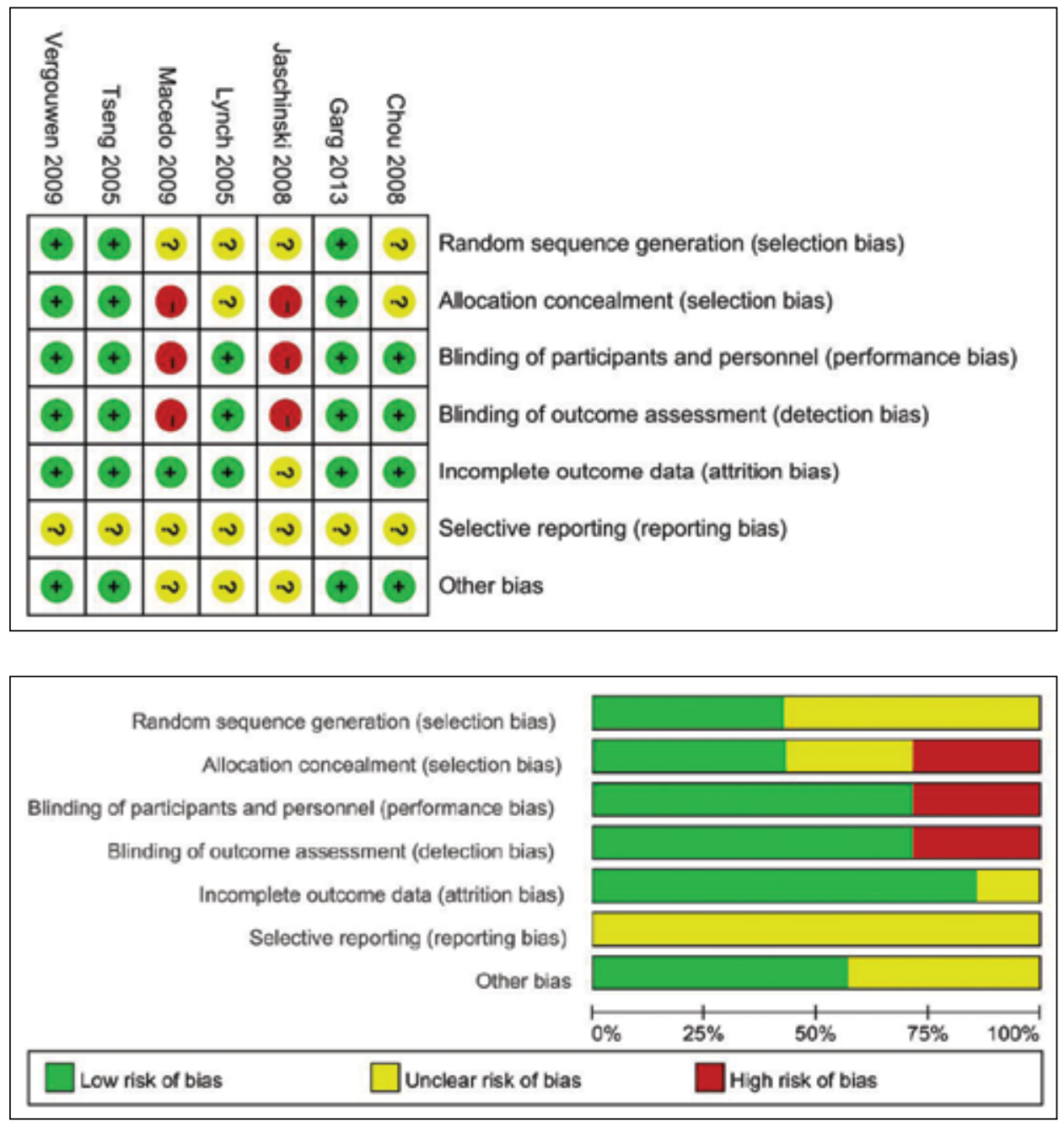

Figure 1: Risk-of-bias summary.

Figure 2: Risk-of-bias graph. 
aminotransferase/alanine aminotransferase $(R R=1.90 ; 95 \% \mathrm{Cl}$, $0.55-6.50 ; p=0.31$ ) (Figure 7), and for these studies, the test result for heterogeneity was low $\left(I^{2}=0 \%, p=0.87\right)$.

\section{DISCUSSION}

Three topics are currently being studied that relate to CVS after
aSAH: endothelin type A receptor antagonists, 3-hydroxy-3methylglutaryl coenzyme A (HMG-CoA) reductase inhibitors for treatment, and cortical spreading depolarization as a mechanism of CVS (21). In this analysis, we focused on statins, a potential addition to the treatment for aSAH, because they are effective for lowering serum cholesterol and have

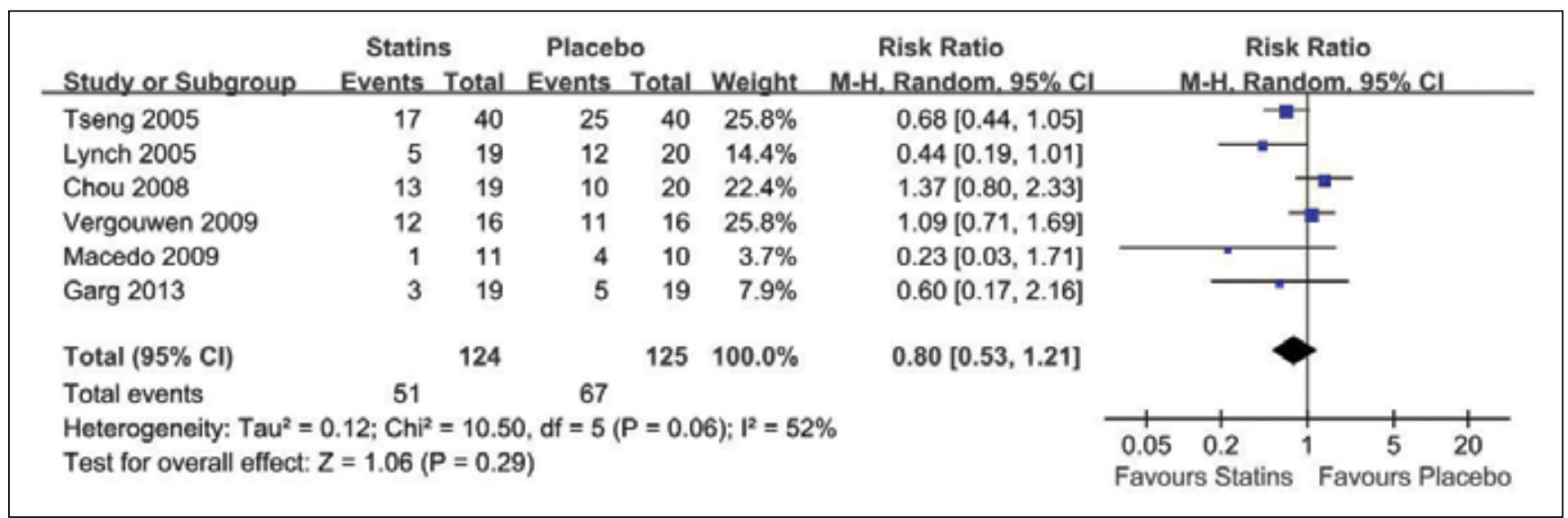

Figure 3: Forest plot of the effect of statins versus placebo on CVS, as seen on TCD.

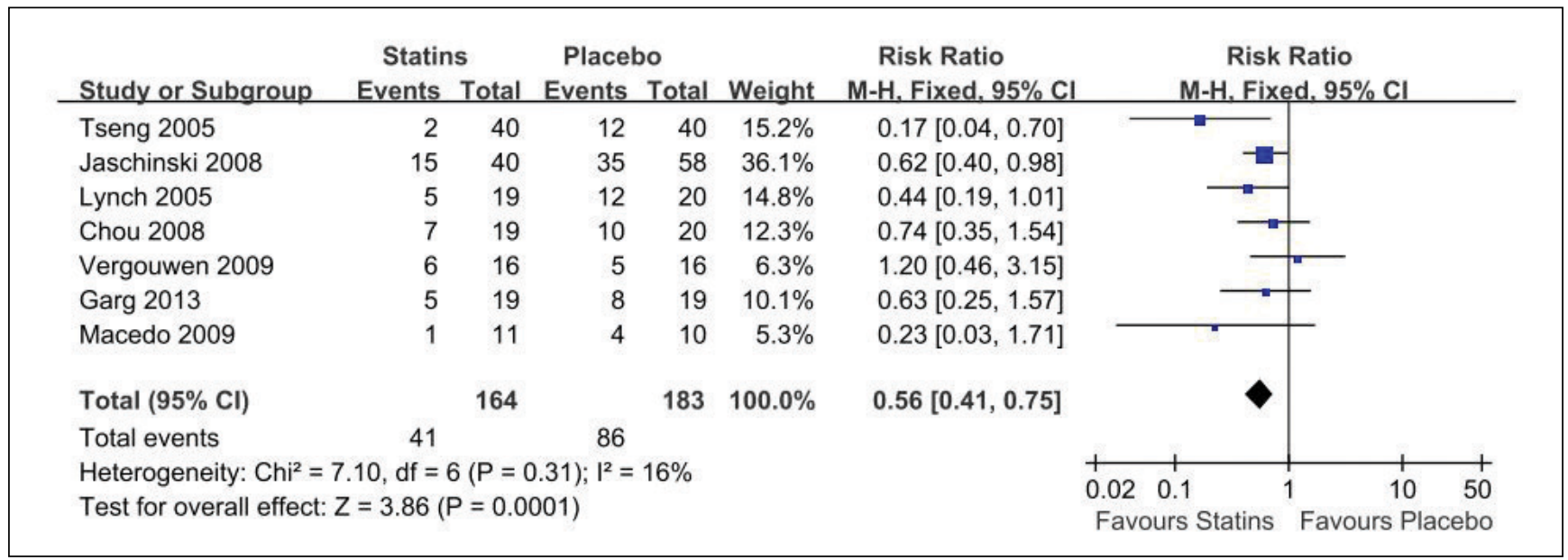

Figure 4: Forest plot of the effect of statins versus placebo on DIND.

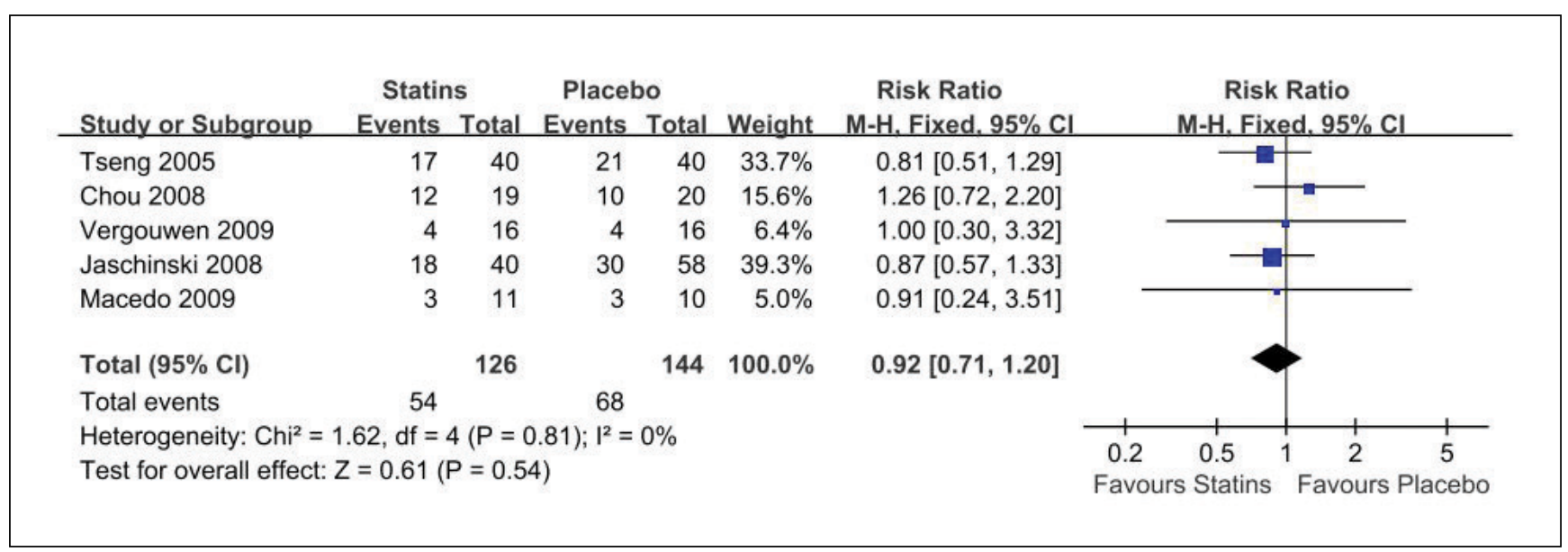

Figure 5: Forest plot of the effect of statins versus placebo on outcomes. 


\begin{tabular}{|c|c|c|c|c|c|c|c|c|c|}
\hline Study or Subgroup & $\begin{array}{l}\text { Statins } \\
\text { Events }\end{array}$ & s & $\begin{array}{l}\text { Placeb } \\
\text { Events }\end{array}$ & Total & Weight & $\begin{array}{c}\text { Risk Ratio } \\
\mathrm{M}-\mathrm{H} \text {. Fixed, } 95 \% \mathrm{Cl}\end{array}$ & $\begin{array}{r}\text { Risk } \\
\text { M-H. Fixe }\end{array}$ & $\begin{array}{l}\text { Ratio } \\
\text { ed. } 95 \% \mathrm{Cl}\end{array}$ & \\
\hline Tseng 2005 & 2 & 40 & 8 & 40 & $24.0 \%$ & $0.25[0.06,1.11]$ & & & \\
\hline Jaschinski 2008 & 9 & 40 & 13 & 58 & $31.9 \%$ & $1.00[0.47,2.12]$ & & & \\
\hline Chou 2008 & 0 & 19 & 3 & 20 & $10.3 \%$ & $0.15[0.01,2.72]$ & & & \\
\hline Vergouwen 2009 & 2 & 16 & 2 & 16 & $6.0 \%$ & $1.00[0.16,6.25]$ & & & \\
\hline Macedo 2009 & 2 & 11 & 6 & 10 & $18.9 \%$ & $0.30[0.08,1.17]$ & & & \\
\hline Garg 2013 & 1 & 19 & 3 & 19 & $9.0 \%$ & $0.33[0.04,2.93]$ & & & \\
\hline Total $(95 \% \mathrm{Cl})$ & & 145 & & 163 & $100.0 \%$ & $0.54[0.32,0.91]$ & & & \\
\hline Total events & 16 & & 35 & & & & & & \\
\hline \multicolumn{7}{|c|}{ Heterogeneity: $\mathrm{Chi}^{2}=5.73, \mathrm{df}=5(\mathrm{P}=0.33) ; \mathrm{I}^{2}=13 \%$} & $0.005 \quad 0.1$ & 10 & 200 \\
\hline \multicolumn{7}{|c|}{ Test for overall effect: $Z=2.31(P=0.02)$} & Favours Statins & Favours Pla & cebo \\
\hline
\end{tabular}

Figure 6: Forest plot of the effect of statins versus placebo on mortality.

\begin{tabular}{|c|c|c|c|c|c|c|c|}
\hline Study or Subgroup & $\begin{array}{l}\text { Statin } \\
\text { Events }\end{array}$ & Iotal & $\begin{array}{l}\text { Placeb } \\
\text { Events }\end{array}$ & Total & Weight & $\begin{array}{c}\text { Risk Ratio } \\
\text { M-H. Fixed. } 95 \% \mathrm{Cl}\end{array}$ & $\begin{array}{c}\text { Risk Ratio } \\
\mathrm{M}-\mathrm{H} \text {. Fixed. } 95 \% \mathrm{Cl}\end{array}$ \\
\hline Lynch 2005 & 1 & 19 & 0 & 20 & $14.1 \%$ & $3.15[0.14,72.88]$ & \\
\hline Chou 2008 & 1 & 19 & 1 & 20 & $28.1 \%$ & $1.05[0.07,15.66]$ & \\
\hline Garg 2013 & 4 & 19 & 2 & 19 & $57.8 \%$ & $2.00[0.41,9.65]$ & \\
\hline Total $(95 \% \mathrm{Cl})$ & & 57 & & 59 & $100.0 \%$ & $1.90[0.55,6.50]$ & \\
\hline Total events & 6 & & 3 & & & & \\
\hline \multicolumn{7}{|c|}{$\begin{array}{l}\text { Heterogeneity: } \mathrm{Ch}^{2}=0.29, \mathrm{df}=2(P=0.87): \mathrm{I}^{2}=0 \% \\
\text { Test for overall effect: } Z=1.02(P=0.31)\end{array}$} & $\begin{array}{lllll}0.002 & 0.1 & 1 & 10 & 500\end{array}$ \\
\hline
\end{tabular}

Figure 7: Forest plot of the effect of statins versus placebo on CK/AST/ALT elevation.

antioxidant, anti-inflammatory, vasodilatory, angiogenic, neuroprotective, vasoprotective, and endothelial preserving effects (19).

Two previous meta-analyses $(22,24)$ focused on statins in 2008 and 2010; however, their results were conflicting. The data in Sillberg et al. (22) supported "the routine use of statins in the care of patients with aSAH" by calculating the odds ratios (ORs) of CVS, DIND, and mortality from 3 RCTs $(2,13$, $23)$, whose results were considered to be subjective $(3,10)$. In contrast, Vergouwen et al. (24) included 4 RCTs $(2,13,23,25)$ whose $R R$ s did not lend statistically significant support to the finding of a beneficial effect of statins in patients with aSAH. In addition, 3 trials addressed this topic during 2009 to 2013, which were necessary to include in another meta-analysis, but Jaschinski et al. (7) and Macedo et al. (14) published only the abstracts, and these had lower methodological quality than comparable studies.

The results of this meta-analysis show that statins are comparable with placebo for reducing DIND and mortality, and these findings are in agreement with those of Sillberg et al. (22). However, these findings show that statins do not reduce CVS as seen on TCD, or improve patient outcomes, similar to the findings of Vergouwen et al. (24). Unlike Sillberg et al. (22) and Vergouwen et al. (24), we tried to compare the time to CVS and DIND from ictus and duration of CVS, but our results were not clear because few data were available to draw firm conclusions; the available data demonstrated that statins tended to shorten the duration of CVS, but not delay the time to CVS and DIND from ictus.

The conclusions of our analysis should be approached with caution for the following reasons: first, many sources of heterogeneity affected the results, and we found different definitions of end points and interference from positive drugs among the studies that may have contributed to statistical heterogeneity and clinical heterogeneity. Two RCTs defined CVS on TCD as mean flow velocities $>120 \mathrm{~cm} / \mathrm{s}$ with a Lindegaard ratio (LR) $>3$ in $\operatorname{MCA}(23,25)$; another 2 RCTs defined CVS as velocities $>160 \mathrm{~cm} / \mathrm{s}(4,13) ; 1 \mathrm{RCT}$ chose velocities $>200 \mathrm{~cm} / \mathrm{s}$ with LR $>3$ (2); and 2 RCTs did not report on the definition $(7,14)$. Because it differs from a more objective indicator, CVS on TCD could have influenced the judgment of patient outcomes. In addition, we found that other positive drugs affected the results in the process. Chou et al. (2) administered an endovascular intervention for CVS, and intra-arterial nicardipine in the statin and placebo groups. All patients in Vergouwen et al. (25) received standard care, including treatment with nimodipine $360 \mathrm{mg} /$ day orally in 2 groups. Owing to differences in definitions and positive drugs 
used among the studies, the heterogeneity of CVS on TCD was great $\left(I^{2}=52 \%, p=0.06\right)$. When effect size was changed to $O R$, results showed no significant difference $(O R=0.59 ; 95 \% \mathrm{Cl}$, $0.28-1.25 ; p=0.17)$, and the test result for heterogeneity was low $\left(I^{2}=40 \%, p=0.14\right)$. When DIND was considered, definitions used by the RCTs were similar, defined as any 2 or more point folds in the modified Glasgow Coma Scale. Statins were able to reduce DIND by $20 \%$ compared with placebo, and the result was relatively stable when excluding lower-quality studies or using a random-effects model. When effect size was changed to $O R$, data showed similar results $(O R=0.38 ; 95 \% \mathrm{Cl}$, $0.24-0.61 ; p<0.0001)$, and the test result for heterogeneity was low $\left(I^{2}=6 \%, p=0.38\right)$. A poor outcome was defined as "dead," "persistent vegetative state," and "severe disability" in the Glasgow Outcome Scale (GOS) or Modified Rankin Scale (MRS), which was similar among the studies, quantitative results stably showing no difference between the 2 groups. These result were similar to previous $R R$ results when the effect size was changed to $O R(O R=0.86 ; 95 \% \mathrm{Cl}, 0.52-1.40 ; p=0.54)$, and the test result for heterogeneity was low $\left(I^{2}=0 \%, p=0.82\right)$. As for mortality, our meta-analysis showed that statins decrease it by $10 \%$ compared with placebo, but it might be an inconsistent effect based on the length of follow-up and the selection of positive drugs; when $O R$ was used as effect size, the result was $O R=0.47 ; 95 \% \mathrm{Cl}, 0.25-0.89(p=0.02)$, and the test result for heterogeneity was low $\left(I^{2}=16 \%, p=0.31\right)$; when a random-effects model was used, the effect on mortality was no longer sufficiently robust to remain statistically significant ( $R R=0.55 ; 95 \% \mathrm{Cl}, 0.30-1.03 ; p=0.06)$. Thus, we suspect that statins play a positive role in improving this outcome.

By comparing data on these outcomes, statins were shown to possibly reduce DIND and mortality, but not CVS on TCD and the likelihood of poor outcomes. We suspect that the choice of acute statins treatment for aSAH is not definitely beneficial, and our results reveal that statins' role is finite. We cannot prove this hypothesis at this stage, however, because relevant data are lacking.

\section{Study Limitations}

This meta-analysis had several potential limitations that should be taken into account. First, statins in this metaanalysis involved pravastatin and simvastatin, which differ from each other (19). We did not analyze them in subgroups because of their few statistical differences and heterogeneity. Second, follow-up was different, as Garg et al. (4) reported the functional outcomes at 1, 3 and 6 months after hospital discharge, while other studies recorded outcomes until patient discharge, which was too short to compare the effectiveness. Third, 2 studies were of poor methodological quality $(7,14)$, and 4 studies were not detailed enough to report randomsequence generation and allocation concealment $(2,7,13$, 14). In addition, we could not obtain original data from articles even though we tried to connect with authors, and 2 trials (7, 14) reported results without particularly detailed information.

\section{CONCLUSION}

Preventing CVS is of great importance. Studies have indicated an increased risk of CVS in patients who are treated with endovascular coiling (17), although surgical clipping of a ruptured aneurysm has not been described as increasing the risk of subsequent CVS $(6,18)$. In the RCTs included in this analysis, patients in 4 trials underwent coiling or clipping procedures $(2,13,23,25)$, and all the patients in 1 trial (4) underwent surgical clipping of an aneurysm. Thus, aSAH and coiling were common reasons for CVS, which might also have contributed to the heterogeneity of these studies. These intriguing clues may be useful for directing future research on this topic.

Further studies should focus on the following points. First, there is a need to report detailed information according to the Consolidated Standards of Reporting Trials and to intentionally enroll patients undergoing clipping or coiling. Second, the definitions of end points should be unified, just as the definition of CVS should be standardized. Third, although statins are generally considered safe and well tolerated, future studies should pay more attention to their safety, especially with regard to rhabdomyolysis and hepatic function.

In conclusion, current limited evidence suggests that statins might be able to decrease DIND and mortality in aSAH, but not CVS on TCD or the risk of poor outcomes. Thus, statins could play a limited role, and acute statins treatment might be not a good choice for CVS after aSAH. Despite these mixed findings, the results of this analysis should be interpreted with caution owing to the heterogeneity among the study designs it included. Further large-scale, well-designed RCTs on this topic are still needed. A RCT of statin therapy for aSAH, expected to enroll 1600 patients, may clarify those answers (15).

\section{REFERENCES}

1. Armitage P, Berry G, Matthews JNS: Analysing means and proportions. In: Statistical Methods in Medical Research. $4^{\text {th }}$ ed. Massachusetts: Blackwell Science Ltd, 2008: 83-146

2. Chou SH, Smith EE, Badjatia N, Nogueira RG, Sims JR, Ogilvy CS, Rordorf GA, Ayata C: A randomized, double-blind, placebo-controlled pilot study of simvastatin in aneurysmal subarachnoid hemorrhage. Stroke 39:2891-2893,2008

3. Cook AM, Hessel EA: Meta-analysis of statins for aneurysmal subarachnoid hemorrhage falls short. Stroke 40:e79,2009

4. Garg K, Sinha S, Kale SS, Chandra PS, Suri A, Singh MM, Kumar R, Sharma MS, Pandey RM, Sharma BS, Mahapatra AK: Role of simvastatin in prevention of vasospasm and improving functional outcome after aneurysmal subarachnoid hemorrhage: A prospective, randomized, double-blind, placebo-controlled pilot trial. Br J Neurosurg 27:181-186, 2013

5. Higgins JP, Thompson SG, Deeks JJ, Altman DG: Measuring inconsistency in meta-analyses. BMJ 327:557-560,2003 
6. Hoh BL, Topcuoglu MA, Singhal AB, Pryor JC, Rabinov JD, Rordorf GA, Carter BS, Ogilvy CS: Effect of clipping, craniotomy, or intravascular coiling on cerebral vasospasm and patient outcome after aneurysmal subarachnoid hemorrhage. Neurosurgery 55:779-789,2004

7. Jaschinski $U$, Scherer K, Lichtwarck M, Forst H: Impact of treatment with pravastatin on delayed ischemic disease and mortality after aneurysmal subarachnoid hemorrhage. Critical Care 12 Suppl 2: 112,2008

8. Kern M, Lam MM, Knuckey NW, Lind CR: Statins may not protect against vasospasm in subarachnoid haemorrhage. J Clin Neurosci 16:527-530,2009

9. King NK, Tay VK, Allen JC, Ang BT: Prior statin use has no effect on survival after intracerebral hemorrhage in a multiethnic Asian patient cohort. Acta Neurochir Suppl 114:343-346,2012

10. Kramer $\mathrm{AH}$ : Statins in the management of aneurysmal subarachnoid hemorrhage--not (yet) a standard of care. Stroke 40:e80-e81,2009

11. Kramer AH, Gurka MJ, Nathan B, Dumont AS, Kassell NF, Bleck TP: Statin use was not associated with less vasospasm or improved outcome after subarachnoid hemorrhage. Neurosurgery 62:422-430,2008

12. Kramer AH, Mikolaenko I, Deis N, Dumont AS, Kassell NF, Bleck TP, Nathan BA: Intraventricular hemorrhage volume predicts poor outcomes but not delayed ischemic neurological deficits among patients with ruptured cerebral aneurysms. Neurosurgery 67:1044-1053,2010

13. Lynch JR, Wang $H$, McGirt MJ, Floyd J, Friedman $A H$, Coon $A L$, Blessing R, Alexander MJ, Graffagnino C, Warner DS, Laskowitz DT: Simvastatin reduces vasospasm after aneurysmal subarachnoid hemorrhage: Results of a pilot randomized clinical trial. Stroke 36:2024-2026,2005

14. Macedo S, Bello Y, Silva A, Siqueira C, Siqueira S, Brito L: Effects of simvastatin in prevention of vasospasm in nontraumatic subarachnoid hemorrhage: Preliminary data. Critical Care 13 Suppl 1: P103,2009

15. Malagos WT, Figueiredo EG: Do statins play a role after subarachnoid hemorrhage? World Neurosurg 74:211-212, 2010

16. Merlo L, Cimino F, Scibilia A, Ricciardi E, Chirafisi J, Speciale A, Angileri FF, Raffa G, Priola S, Saija A, Germano A: Simvastatin administration ameliorates neurobehavioral consequences of subarachnoid hemorrhage in the rat. J Neurotrauma 28:2493-2501,2011

17. Moskowitz SI, Ahrens C, Provencio JJ, Chow M, Rasmussen PA: Prehemorrhage statin use and the risk of vasospasm after aneurysmal subarachnoid hemorrhage. Surg Neurol 71:311318,2009
18. Pathak A, Mathuriya SN, Khandelwal N, Verma K: Intermittent low dose intrathecal sodium nitroprusside therapy for treatment of symptomatic aneurysmal SAH-induced vasospasm. Br J Neurosurg 17:306-310,2003

19. Sabri M, Macdonald RL: Statins: A potential therapeutic addition to treatment for aneurysmal subarachnoid hemorrhage? World Neurosurg 73:646-653,2010

20. Sanchez-Pena P, Nouet A, Clarencon F, Colonne C, Jean B, Le Jean L, Fonfrede M, Aout M, Vicaut E, Puybasset L: Atorvastatin decreases computed tomography and S100-assessed brain ischemia after subarachnoid aneurysmal hemorrhage: A comparative study. Crit Care Med 40:594-602,2012

21. Sasaki T, Kikkawa Y: Proposed mechanism of cerebral vasospasm: Our hypothesis and current topics. Acta Neurochir Suppl 115:53-56,2013

22. Sillberg VA, Wells GA, Perry JJ: Do statins improve outcomes and reduce the incidence of vasospasm after aneurysmal subarachnoid hemorrhage: A meta-analysis. Stroke 39:26222626,2008

23. Tseng MY, Czosnyka M, Richards H, Pickard JD, Kirkpatrick PJ: Effects of acute treatment with pravastatin on cerebral vasospasm, autoregulation, and delayed ischemic deficits after aneurysmal subarachnoid hemorrhage: A phase II randomized placebo-controlled trial. Stroke 36:16271632,2005

24. Vergouwen MD, de Haan RJ, Vermeulen M, Roos YB: Effect of statin treatment on vasospasm, delayed cerebral ischemia, and functional outcome in patients with aneurysmal subarachnoid hemorrhage: A systematic review and metaanalysis update. Stroke 41:e47-e52,2010

25. Vergouwen MD, Meijers JC, Geskus RB, Coert BA, Horn J, Stroes ES, van der Poll T, Vermeulen M, Roos YB: Biologic effects of simvastatin in patients with aneurysmal subarachnoid hemorrhage: A double-blind, placebo-controlled randomized trial. J Cereb Blood Flow Metab 29:1444-1453,2009

26. Yilmaz A, Aydin MD, Kanat A, Musluman AM, Altas S, Aydin Y, Calik M, Gursan N: The effect of choroidal artery vasospasm on choroid plexus injury in subarachnoid hemorrhage: experimental study. Turk Neurosurg 21:477-482,2011

27. Yuksel S, Tosun YB, Cahill J, Solaroglu I: Early brain injury following aneurysmal subarachnoid hemorrhage: Emphasis on cellular apoptosis. Turk Neurosurg 22:529-533,2012

28. Zacharia BE, Hickman ZL, Grobelny BT, DeRosa P, Kotchetkov I, Ducruet AF, Connolly ES Jr: Epidemiology of aneurysmal subarachnoid hemorrhage. Neurosurg Clin N Am 21:221233,2010 